\title{
Mycenaean Textile Memories in Homeric Terminology
}

\author{
By Valentina Gasbarra*
}

\begin{abstract}
The present paper aims at investigating continuity and disruption between Mycenaean and Homeric Greek in the field of technical terminology pertaining to the textile craft. The objective of the work is

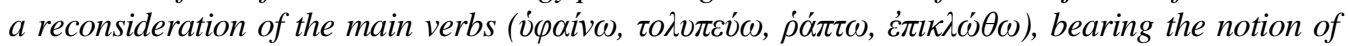
"to weave", into these two phases of the Greek language. The analysis is primarily conducted from a linguistic point of view, evaluating the formal affinity or diversity between the $2^{\text {nd }}$ and the $1^{\text {st }}$ millennium Greek and, if possible, in comparison with other cognate languages. We can highlight even the semantic shift - in the reason of the different chronology and contexts of use - which characterises the textile terminology. We know, indeed, that the use of the terminology of work (particularly of the manual labour) in relation with the terminology for intellectual activities (planning, ideation, writing, playing music etc.) can be considered a topos in many Indo-European traditions. Following this path of reasoning, most of the terms in the Linear B tablets drawn for manufacturing crafts (such as carpentry or weaving) assume in the Homeric epics a metaphorical meaning.
\end{abstract}

Keywords: Homeric Greek, Indo-European background, Metaphorical sense, Mycenaean Greek, Textile terminology

\section{A Preliminary Overview}

The knowledge of the Mediterranean Bronze Age culture has increasingly expanded our interpretation and our reading of the Homeric texts: nowadays the close connection and the continuity of cultural forms from the Mycenaean into the Homeric world (see, among the wide literature on this topic, the two following recent works: Deger-Jalkotzy and Lemos 2006, and Shelmerdine 2008) is a fact. Archaeology has primarily revealed continuing contacts between the Aegean world and the cultural sphere of the Homeric poems, and these contacts can also be evaluated in terms of specialized terminology, particularly in strict reference to the sphere of power and work (Morpurgo Davies 1979). As masterfully highlighted by Morpurgo Davies (1979), a close analysis of the lexicon surely demonstrates the deep changes both in the basic administration and organization of the state, and in the terminology of crafts and occupational words; however it is possible to trace a particular sort of continuity between Linear B and later evidence. So, the technical terminology between the Mycenaean period and the $1^{\text {st }}$ Millennium period shows a lot of disruption, but also a limited amount of continuity at a less sophisticated level (Morpurgo Davies 1979: 105).

Particularly, we can outline a well-structured framework in the field of textile crafts in Linear B documents: the textile industry - connected with the entire manufacture process of raw materials (wool and flax) - occupies a prominent position in the four largest archives (Knossos, Pylos, Thebes, and Mycenae) and it has been deeply investigated by scholars (Killen 1984, Del Freo et al. 2010, Del Freo and Rougemont 2012).

${ }^{*}$ Postdoc Fellow, "Sapienza" University of Rome, Italy. 
The reason of such interest in the textile industry is obviously related with the economic organization of the palace administration: the palace had an interest in production of raw material and monitored each stage of the process. Although the Linear B tablets do not give us a clear description of technical procedures, we can surely maintain that activity was carried out by specialized craftspeople. In particular, as widely demonstrated by the interpretation of the Mycenaean texts, as well as easily remarkable in Homer, the textile activities are domain of women, who contribute with their handiwork not only to the economy (Killen 1984, Del Freo et al. 2010, Del Freo and Rougemont 2012), but also to the care of their household ${ }^{1}$.

The Iliad and Odyssey contain a huge range of textile terms used for the description of women weaving or sewing (Nosch 2014a), but that textile terminology is also metaphorically used to refer to the actions of men and

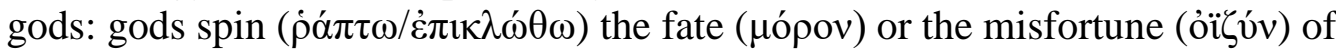

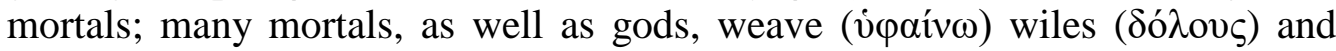
cunning $(\mu \tilde{\eta} \tau \mathrm{\imath})$; men were involved in a war as yarn wind up into a ball

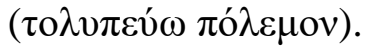

The language used in these formulaic metaphors proves the deep interconnection between the two registers (McIntosh Snyder 1981: 193-196): weaving is closely linked in the Greek mind to the act of planning or contriving, and this semantic shift has a strong connection with the interaction between terminology of crafts and intellectual activity (ideation, writing, playing music etc.) recognizable in the Indo-European background ${ }^{2}$.

\section{Research Objectives and Methodological Remarks}

Starting from what was asserted in the previous paragraph, I do not intend to offer new interpretations of these forms. They have just been discussed more than once, and - as we evidence below - sometimes their etymology remains obscure. Instead, the purpose of the present paper is a reconsideration of the particular path followed by that technical terminology in the passage from the $2^{\text {nd }}$ to the $1^{\text {st }}$ millennium $\mathrm{BC}$, and it is also noteworthy to establish a parallel with other cognate traditions, where it is possible.

The work is carried out following the strict criteria of comparativereconstructive linguistics, for this reason the data are placed side by side in order to find any systematic correspondence between the two stages of the Greek language. The tools used for the collection of data are the editions of the Mycenaean texts and the lexicon of Homeric dialects (Cunliffe 2012). The analysis also benefited from the use of the main etymological dictionaries of the Greek language (DELG, EDG) and by the Mycenaean dictionary (DMic).

\footnotetext{
${ }^{1}$ For spinning and weaving as symbols of domestic order, see Pantelia (1993).

2 Cf. the well known example of the Latin texō,-ere "to weave, construct" and the related formulaic expression sermōnes texere "weaving words".
} 


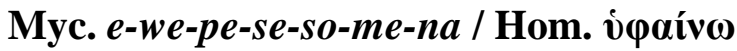

The weaving technique is obviously a common heritage to Indo-European cultures and for this reason we can identify a common root *webh- to express the notion ${ }^{3}$. Both Mycenaean and later the Greek demonstrate the presence of the root: the Mycenaean future participle e-we-pe-se-so-me-na (Gr. $\dot{\varepsilon} F \varepsilon \psi \eta \sigma o ́ \mu \varepsilon v \alpha$ "which will be woven/are ready to be woven") may prove that the root was *webh- (with the $e$-vocalism), as well as the Greek verb v $\varphi \alpha i v \omega^{4}$. The etymology of the Mycenaean form is however disputed, because some scholars ${ }^{5}$ have interpreted it as the future participle passive of the verb $\tilde{\varepsilon} \psi \omega$ "to boil": $\varepsilon \hat{\tilde{\varepsilon}} \dot{\varepsilon} \psi \eta \sigma o ́ \mu \varepsilon v \alpha$, "to be well boiled".

As it is shown in Table 1, the participle e-we-pe-se-so-me-na represents an hapax: it is attested in only one tablet in Mycenae, in the context of the wool industry $^{6}$, and in connection with a specific typology of woollen (as indicated by the ideogram LANA) cloths, $p a-w e-a_{2}$ (or variant $p a-w e-a$, Gr. $\varphi \alpha ́ \rho F \varepsilon \alpha$, "linen, cloth, garment, cloak, costume").

Table 1

\begin{tabular}{|l|l|}
\hline MY Oe 127 & pa-we- $a_{2}, e$-we-pe-se-so-me-na, LANA 20 \\
\hline
\end{tabular}

If - theoretically - the two interpretations are possible both from the meaning itself (in any case, the future participle $e$-we-pe-se-so-me-na describes a process pertaining the wool manufacture) and from the linguistic point of view, nevertheless the connection with the Indo-European root *webh- seems to be preferred.

The textile technique belongs to the entire Indo-European cultural background and most of Indo-European languages show the existence of that root. In this sense, the data from Linear B documents can undoubtedly be evaluated in connection with the cognate forms: Skt. ubhnâti "tightens, ties, forces"; YAv. ubdaena "woven"; Av. vaf "weave"; Alb. ven "weave"; OHG weban "to weave, twist, spin"; TocA wäp-, TocB wäp- "to weave". It is however possible to go further: in many of the just recalled Indo-European traditions the use of the words derived from the root $*_{w e b h}$ - is not limited to the proper meaning, but it is also widening to a lot of metaphorical uses ${ }^{7}$.

\footnotetext{
${ }^{3}$ See DELG and EDG s.vv.

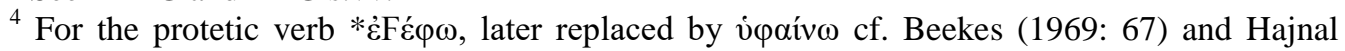
(2002).

5 See lastly Bichlmeier (2014: 38). The hypothesis was also sketched in DELG s.v. Ě $\psi \omega$, although strongly rejected by Palmer (1963: 421) and Perpillou (1996: 58 and 203)

${ }^{6}$ For a recent survey of Mycenaean wool industry, see Nosch (2014b).

${ }^{7}$ West (2007: 36-37) quotes the passages of Rgveda and Avesta in which the terms used to express the notion of "weave" have come to mean "sign of, hymn".
} 
Table 2

\begin{tabular}{|c|c|}
\hline 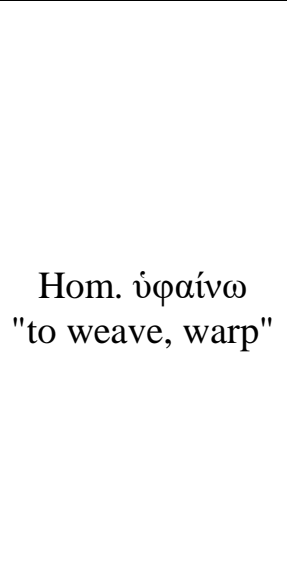 & 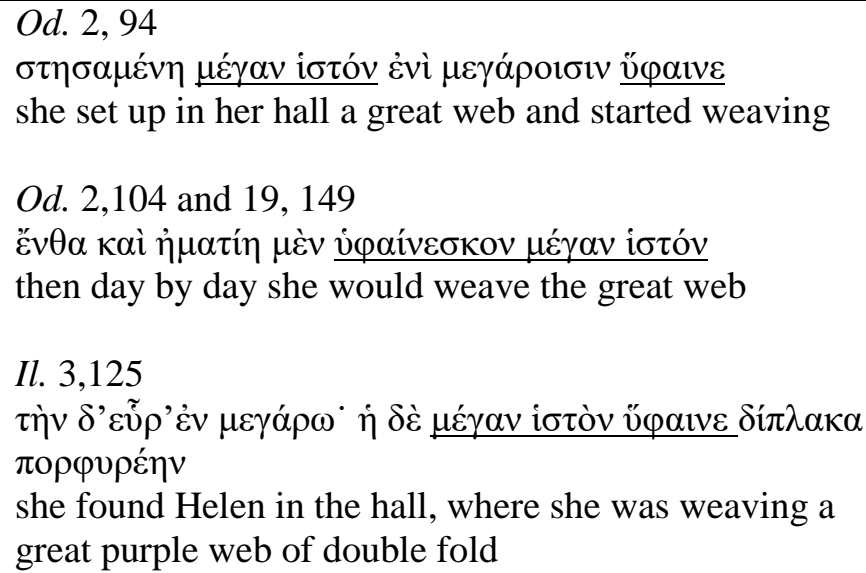 \\
\hline
\end{tabular}

Table 3

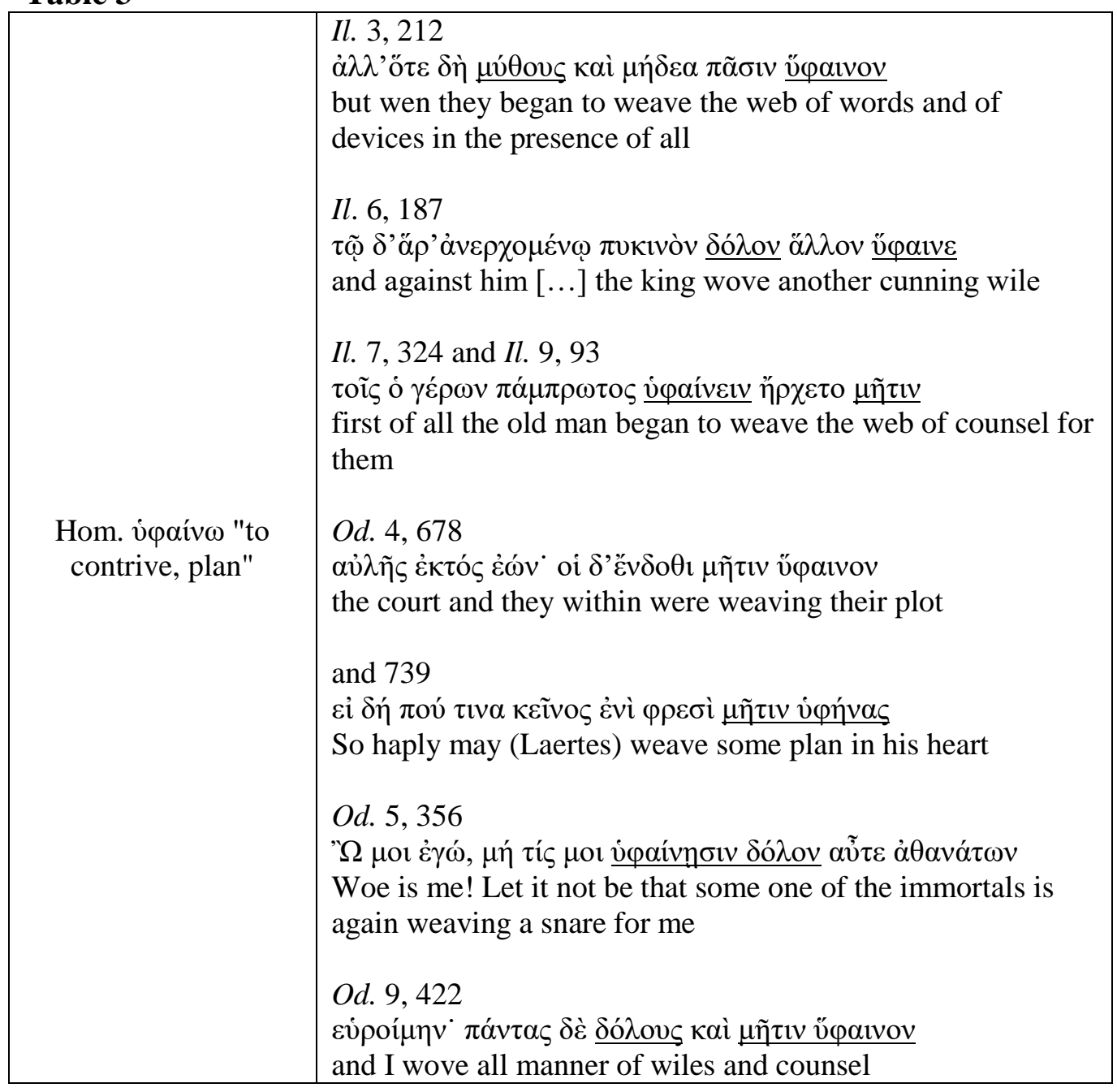

In the $1^{\text {st }}$ millennium, the verb v́paiv $\omega$ (and its derivatives of course) has a wide range of attestations throughout the Greek literature from its beginning to 
Late Antiquity. The Homeric epic tradition ${ }^{8}$ proves the twofold meaning: the verb v́qív $\omega$ is used in the proper technical sense of "to weave", but mostly it is used in the metaphorical sense of "to plan, to contrive", in association with

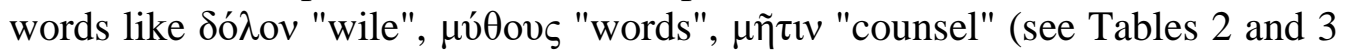
for some examples).

\section{Myc. e-ra-pe-me-na / Hom. ра́ $\tau \tau \omega$}

The etymology of the verb is deeply debated, because the presence of the Mycenaean form (the perfect participle e-ra-pe-me-na, errhap (h)mena, "sewn, stitched"), has changed the traditional interpretation according to which the Greek verb $\dot{\rho} \alpha \dot{\tau} \tau \omega$ is connected with the Baltic forms (with initial $w$-) like Lit. verrpti "to spin"; Latv. virpêt "to spin with a spindle" etc. from the root *werp ${ }^{9}$.

We have no certain etymology for the Greek verb, and the presence of the Mycenaean counterpart, e-ra-pe-me-na, has conducted García Ramón (1985: 218-219 and 225) to assume for $\rho \alpha ́ \pi \tau \omega$ a zero-grade root from $*_{s} s e b^{h}-{ }^{*} s_{\circ} r b^{h}$-.

In the Mycenaean texts the appellative ra-pte(-re) (attested in Pylos and Knossos archives) is also attested, which may stand for the Gr. * ${ }^{*} \alpha \pi \tau \tilde{\eta} \rho$ "sewer, tailor" ${ }^{10}$, the adjective ra-pte-ri-ja (Gr. * $\dot{\rho} \alpha \pi \tau$ pı $\left.\alpha \iota\right)$ and the appellative

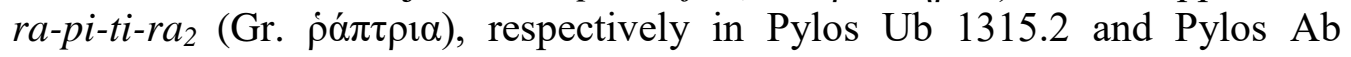
555.B. All these terms - although the debate of their meaning is, in a certain sense, open ${ }^{11}$ - seem to be reconducted to Gr. pó $\pi \tau \omega$, and they also belong to the semantic sphere of the textile craft.

The context, in which the Mycenaean form e-ra-pe-me-na is attested, tends to confirm the relationship with the textile industry (see also the presence of textile ideogram "TELA", Table 4).

Table 4

\begin{tabular}{|c|c|}
\hline KN L 647.B & ]ra, e-ni-qe e-ra-pe-me-na "nu-wa-ja" TELA; \\
\hline
\end{tabular}

In the Homeric poems the verb is once used in the sense of "to sew, to stitch", but many occurencies show the meaning "to devise, contrive, plan" (see

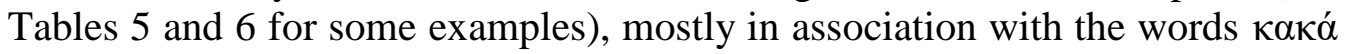

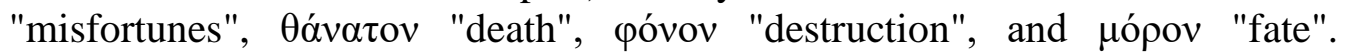
Moreover the term $\dot{\rho} \alpha \psi \omega \delta$ ó $\varsigma$, not attested in Homer, is composed by a first verbal member ( $\dot{\rho} \alpha \dot{\tau} \tau \omega)$ and by a second nominal one ( $\dot{\alpha} 01 \delta \dot{)})$, and the literal translation can be "he who sews together the song (= poet)".

\footnotetext{
${ }^{8}$ The English translations of the Homeric poems are by A.T. Murray (1919 and 1924).

${ }^{9}$ Cf. LIV, DELG, EDG s.vv.

${ }^{10}$ See Morpurgo Davies (1963: s.v.).

11 We refer to DMic s.v. for the different interpretations and - particularly - for the vast literature related.
} 
Table 5

\begin{tabular}{|c|c|}
\hline ṕá $\pi \omega \omega$ "to sew, stitch" & 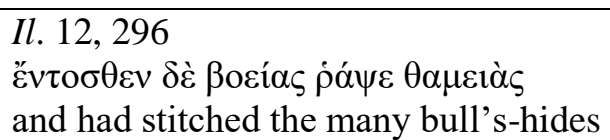 \\
\hline
\end{tabular}

\section{Table 6}

\begin{tabular}{|c|c|}
\hline $\begin{array}{c}\text { já } \pi \tau \omega \text { "to contrive, plan, } \\
\text { plot" }\end{array}$ & 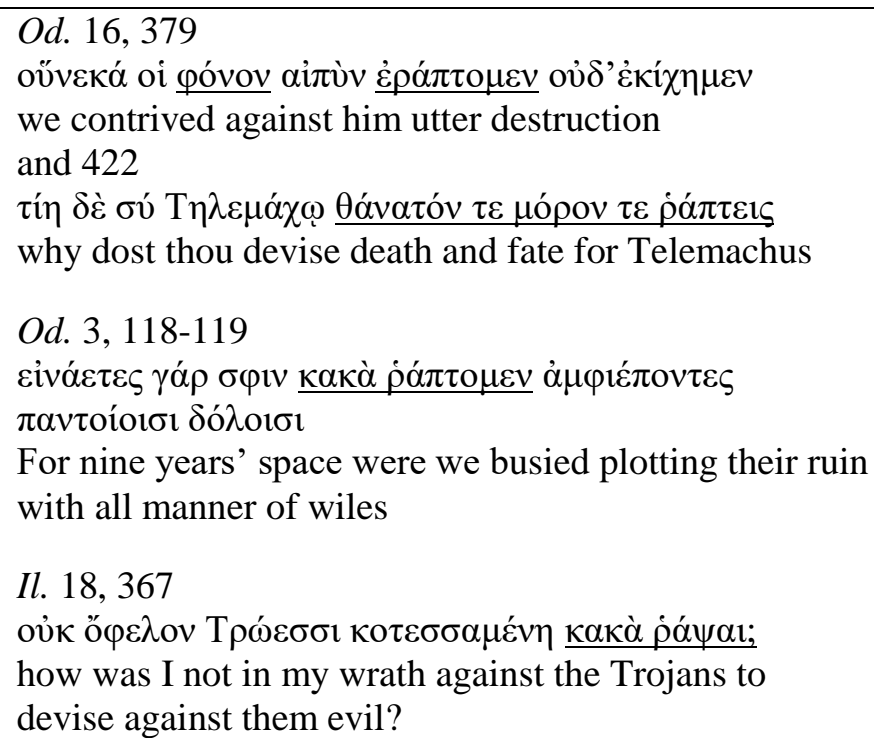 \\
\hline
\end{tabular}

\section{Hom. $\tau 0 \lambda v \pi \varepsilon v ́ \omega$}

The verb $\tau 0 \lambda v \pi \varepsilon v ́ \omega$ "to wind wool or yarn into a clew" is not attested in the Linear B documents ${ }^{12}$. It is - probably - a derivative from the word $\tau 0 \lambda v i \pi \eta$ "a clew of wool or yarn".

The Gr. $\tau 0 \lambda \hat{v} \pi \eta$ is probably a loanword, which is modelled on the Luwian and Hittite form taluppa-/i- (Melchert 1993: 203) "clod (of land, of clay)", "ball shaped cakes". According to Melchert (1998), on the basis of the work of Joseph (1982), the presence of the word both in Hittite and in Luwian could cronologically and geographically reinforce the hypothesis of a loanword from Anatolia. In his recent analysis, Melchert (1998: 47-51) reads the verbs talupp-/tarupp- "to gather, collect (into a globular mass), unite" and the noun taluppa/ $i$ - as closely connected, postulating that "the latter is a deverbative animate action/result noun that is moderately productive in Hittite and in Luwian" (Melchert 1993: 48).

If the relation between Anatolian and Greek languages is quite secure, the question of the original shape of the verb stem and its source (that means if it is Indo-European or not $^{13}$ ) remains effectively problematic. For this reason, in absence of clear and definitive etymology, many scholars tend to relate the word to a Pre-Greek substrate, which must have spoken in large part of Anatolia as well ${ }^{14}$.

\footnotetext{
12 The Mycenaean word tu-ru-pte-ri-ja - connected by Maurice (1991) with Gr. $\tau 0 \lambda v \varphi \alpha ́ v \tau \eta \varsigma$

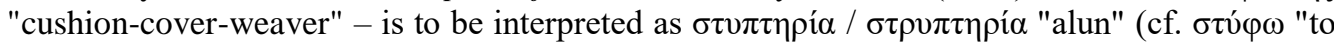
astringe, have an astringent effect".

${ }_{13}$ Melchert (1998: 50) suggests the possibility of connecting Hitt. tarupp- to the root * rewp-.

${ }^{14}$ See lastly EDG s.v.
} 
The Mycenaean lexicon does not display the form, but the Iliad and the Odyssey show the following use of the verb: firstly in connection with $\pi \mathrm{o} \lambda \varepsilon \dot{\mu} \mathrm{ov} / \pi \mathrm{o} \lambda \varepsilon \varepsilon_{\mu} \mathrm{v}_{\zeta}$ or $\delta$ ó $\lambda \mathrm{ov}$, "to wind up the skein of war/wile"; secondly, in connection with $\alpha \hat{\lambda} \gamma \varepsilon \alpha$, with the meaning "to wind up woes", (see Tables 7 and 8 ). It is noteworthy that the verb is never used in its proper meaning, that means in relation to textile activities, but its use is only limited to these secondary meanings.

Table 7

\begin{tabular}{|c|c|}
\hline $\begin{array}{c}\tau 0 \lambda v \pi \varepsilon v ́ \omega \\
\text { "to wind up (the skein of } \\
\text { war/wile)" }\end{array}$ & 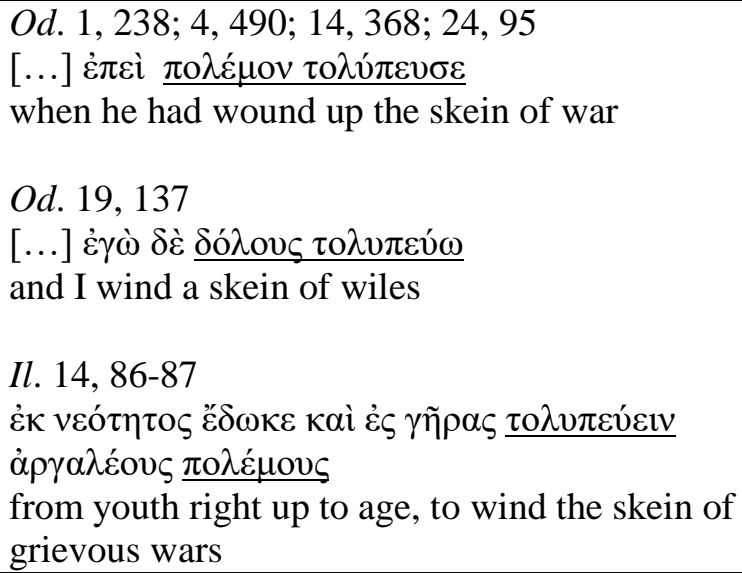 \\
\hline
\end{tabular}

Table 8

\begin{tabular}{|c|c|}
\hline $\begin{array}{c}\tau \circ \lambda v \pi \varepsilon v ́ \omega \\
\text { "to wind up (woes)" }\end{array}$ & 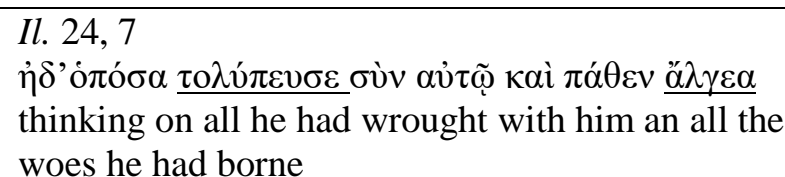 \\
\hline
\end{tabular}

\section{Myc. ko-ro-to? / Hom. $\dot{\varepsilon} \pi \mathrm{\iota} \lambda \omega \dot{\theta} \omega$}

The etymology of the verb $\kappa \lambda \omega \theta \omega$ "to spin" has always connected with the

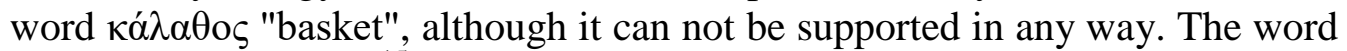
is probably Pre-Greek ${ }^{15}$. It is noteworthy that the verb $\kappa \lambda \omega \theta \omega$ is mostly used in

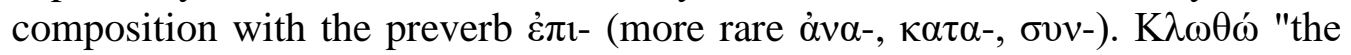
spinster" is the name of one of the Moirai (Hes. Th. 905). The Mycenaean archives show the adjective ko-ro-to (Table 9), but the interpretation of the form is really disputed: it has been connected with the verb $\kappa \lambda \omega \theta \omega$ (klosston "spun") (Chadwick and Baumbach 1963: 210), but also with the verb $\chi \rho \omega ́ \zeta \omega$ (khrōston "dyed") (Del Freo, Nosch and Rougemont 2010: 344 and 368). Both the hypothesis remain uncertain, the only given datum is the presence of the textile ideogram (LANA), that seems to relate the word to a technical process connected with the wool processing.

${ }^{15}$ See DELG and EDG s.v. 
Table 9

\begin{tabular}{|l|l|}
\hline MY Oe 106 & $\begin{array}{l}\text { to-te-we-ja-se-we ko-ro-to LANA 1 } \\
\text { KN Od } 486\end{array}$
\end{tabular}

In the Homeric poems the composed verb $\dot{\varepsilon} \pi \mathrm{l}-\kappa \lambda \omega \theta \omega$ is quoted into 7 different passages of the Odyssey, once in the Iliad. In most cases it is used for the general description of gods who "spin" the destiny of mortals (see Table 10 for some examples). In other attestations the verb is used in connection with the word ö $\lambda \beta$ ov "prosperity, good fortune, happiness", or, on the contrary with the word öỉovv "trouble, misfortune" (Table 11).

\section{Table 10}

\begin{tabular}{|c|c|}
\hline $\begin{array}{c}\dot{\varepsilon} \pi \iota \kappa \lambda \omega ́ \theta \omega \\
\text { "to spin (destiny, fate)" }\end{array}$ & 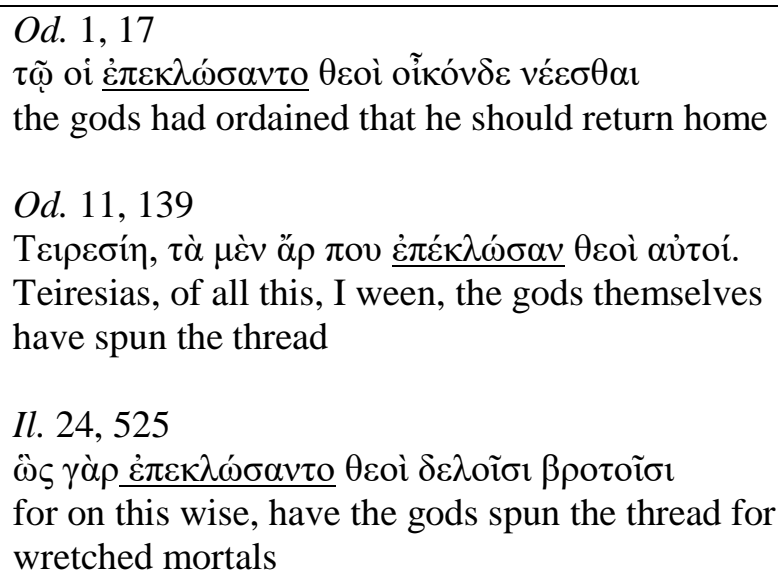 \\
\hline
\end{tabular}

Table 11

\begin{tabular}{|c|c|}
\hline $\begin{array}{c}\dot{\varepsilon} \pi 1 \kappa \lambda \omega \theta \omega \\
\text { "to spin (fortune, } \\
\text { happiness/trouble, } \\
\text { misfortune)" }\end{array}$ & 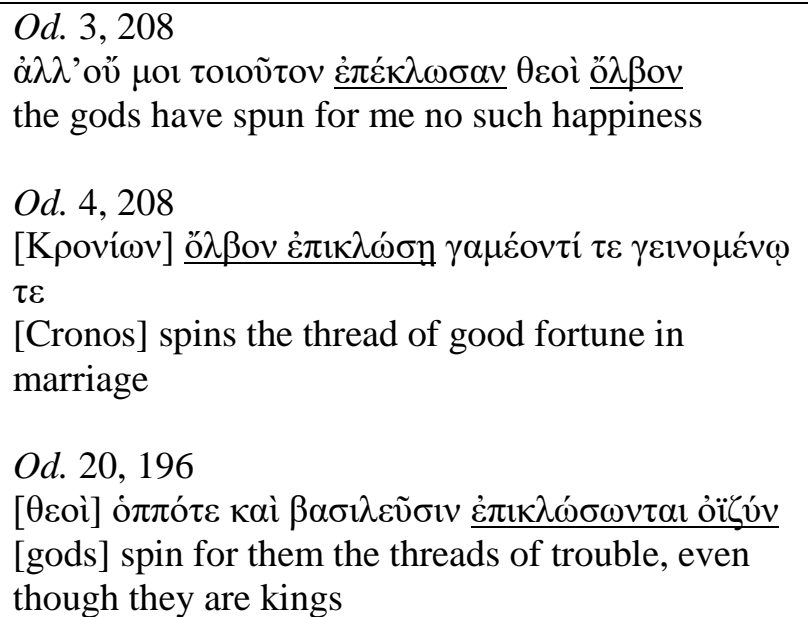 \\
\hline
\end{tabular}




\section{"To Weave" some Brief Considerations}

The ancient art of weaving - well known to most primitive populations origins a series of metaphors in the Indo-European linguistic patrimony. Among these images, the most common - and probably not only prerogative of the IndoEuropean languages ${ }^{16}$ - is the literary metaphor of poetry, or, more generally, the metaphor of narration. Just to give a clear exemplification, we can remark that in Indo-Iranian, Greek, Celtic, and Germanic the poetic composition is described in terms of weaving (Durante 1960: 8-9, Schmitt 1967: 300-301, Campanile 1977: 36 ff., West 2007: 36-38, Watkins 1995: 117): the rhythmic action of weaving process becomes a metaphor for speech and poetic composition, and that fact can surely confirms the idea that this common feature is rooted in the prehistory and it is shared by many Indo-European languages. Moreover, in ancient terminology and phraseology the combination between poetic creation and artistic or craft activities (poetry connected with construction, carpentry, and blacksmithing) is really common, but it is noteworthy that this comparison is suggested by activities which require a high degree of technical expertise and which have to be made or to be prepared with skill ${ }^{17}$. The figure of the so called "craftsman-poet" will become a topical motive in the post-Homeric Greek literature (e.g. Stesichorus, Theognis, Solon), but also in many other literary traditions, and that feature is not limited to the antiquity, but seems to have a more advanced chronological extent ${ }^{18}$.

As shown above, thanks to the analysis conducted on the verbs for "to weave", the terminology for textiles and textile production seem to occupy two separate linguistic registers in the Homeric epics, which play in a continue interchange, according to which words and thoughts are "woven" or "sewn" as a web and the act of devising or contriving is seen and perceived as a woven cloth.

It is also possible - to strengthen this comparison - to evaluate another term related to textile industry, which is used in a metaphorical sense. The Mycenaean word ri-no ${ }^{19}$, Greek $\lambda$ ívov "linen, flax, linen cloth, thread, cord, fishing net", attested in Pylos and Knossos archives, as well as the two related syllabograms (SA and RI), which generally identifies the name of the plant ${ }^{20}$, it is also used in Homeric poems in the metaphorical meaning of "thread of destiny" (cf. Il. 20, 128 or Od. 7, 198). Moreover the image of the "thread", not only in relation with fate, but in reference to the speech is really common in the Greek mythology and phraseology, as well as in the linguistic heritage of many Ancient and Modern languages.

\footnotetext{
${ }^{16}$ As evidenced by Durante (1960), who makes reference to the Arabic verb $h \bar{a} k$ "to weave" and "to narrate"; or to the Mandarin Chinese pien "to weave, interlace" and "to narrate, compose".

${ }^{17}$ See Durante (1960: $5 \mathrm{ff}$.) for the analysis of some verbs related to poetic activity, which contain the notion "to make", or better "to make with skill".

${ }^{18}$ Among many (possible) others, an example might be The Divine Comedy of the Italian poet Dante Alighieri, in which the poet is seen as fabbro del parlar "blacksmith of words" (Purg. XXVI, 117).

${ }^{19}$ Moreover, the term $\lambda$ ívov seems to have an obscure etymology too, and it probably belongs to the category of "Mediterranean words", cf. EDG s.v.

${ }^{20}$ For a close epigraphical analysis of flax and linen in the Mycenaean documents, see Del Freo, Nosch and Rougemont (2010: 344-345).
} 


\section{Concluding Remarks}

The typology of Mycenaean documentation does not allow to evaluate the presence of secondary uses of textile terminology, because - as known - the Mycenaean archives, nowadays discovered, consist only in bureaucratic inventories and lists. However, as it often happens when dealing with such a typology of fragmentary language, it does not mean that the metaphorical use does not exist in the practice of the everyday spoken language or in the practice of a Mycenaean literature (if it had existed, although it is not preserved in a written form ${ }^{21}$ ).

The standing point is the linguistic conservatism between Linear B Greek and Homeric Greek in relation to the textile terminology. Linear B tablets provide a rich and complex textile terminology (more than the present analysis has highlighted), concerning several typologies of cloths, garments, decorations, as well as a huge amount of textile workers (male and female), as a real evidence of the importance of this industry inside the society. On the other hand, the succeeding changes occurred in that part of the vocabulary that indicates substantial cultural change, or better, technological change, which obviously can be achieved between the $2^{\text {nd }}$ and the $1^{\text {st }}$ millennium, and beyond. That patrimony of knowledge and of language from the Aegean Bronze Age come into the Homeric epics, and exploiting the cognitive affinity between technical know-how connected to the textile activities and the elaboration of words and thoughts, become the ground on which the primary meaning of

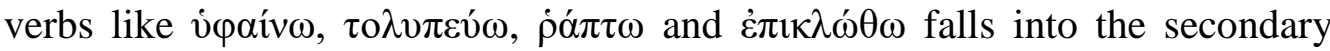
senses of plotting, contriving and devising.

\section{Acknowledgements}

This paper is the result of a study sponsored and financed in 2014 by Sapienza - University of Rome ("La terminologia tessile nel Mediterraneo orientale e Vicino Oriente Antico tra II e I millennio a.C. Lingue, culture e contatti").

\section{References}

Beekes RSP (1969) The Development of the Proto-Indo-European Laryngeals in Greek. The Hague: Mouton.

Bichlmeier H (2014) Studien zur Verwendung der Lokalpartikeln im Mykenischen (Studies on the Use of Local Particles in Mycenaean). Wiesbaden: Reichert Verlag.

Campanile E (1977) Ricerche di cultura poetica indoeuropea (Studies on IndoEuropean Poetic Culture). Pisa: Giardini.

Chadwick J, Baumbach L (1963) The Mycenaean Greek Vocabulary. Glotta 41(3/4): 157-271.

\footnotetext{
${ }^{21}$ In this respect, for a vast survey about the Mycenaean origin of Homeric poetry see Hooker (1988: 57-64).
} 
Cunliffe RJ (2012) A Lexicon of Homeric Dialect. Expanded Edition. With a New Preface by J.H. Dee. Norman, OK: University of Oklahoma Press.

Deger-Jalkotzy S, Lemos IS (2006) Ancient Greece: From the Mycenaean Palaces to the Age of Homer. Edinburgh Leventis Studies 3. Edinburgh: Edinburgh University Press.

Del Freo M, Nosch ML, Rougemont F (2010) The Terminology of Textiles in the Linear B Tablets, including Some Considerations on Linear A Logograms and Abbreviations. In $\mathrm{C}$ Michel, ML Nosch (eds.), Textile Terminologies in the Ancient Near East and the Mediterranean from the 3rd to the 1st Millennium BC, pp. 338-373. Oxford: Oxbow.

Del Freo M, Rougemont F (2012) Observations sur la série Of de Thèbes (Observations on the Of series of Thebes). Studi Micenei ed Egeo Anatolici 54: 263-280.

DELG = Chantraine P (1968-1980) Dictionnaire étimologique de la langue grecque (Etymological Dictionary of the Greek Language). Paris: Klincksieck.

DMic = Aura Jorro F (1985-1993) Diccionario Micénico (Mycenaean Dictionary). Madrid: Consejo Superior de Investigaciones Científicas.

Durante M (1960) Ricerche sulla preistoria della lingua poetica greca: la terminologia relativa alla creazione poetica (Studies on the Prehistory of Greek Poetic Language: the Terminology of Poetic Creation). Accademia Nazionale dei Lincei - Estratto dai Rendiconti della Classe di Scienze morali, storiche e filologiche Series 8, XV(5-6): 1-19.

EDG = Beekes RSP (2010) Etymological Dictionary of Greek. Leiden - Boston: Brill.

García Ramón JL (1985) The Spellings $T a$ and $T a-r a$ for Inherited ${ }^{*} T r$ in Mycenaean: Sound Law, Phonetic Sequence and Morphological Factors at Work. Minos 19: 195-226.

Hajnal I (2002) Mykenisch e-we-pe-se-so-me-na und die Frage eines frühgriechischen Umlauts (Mycenaean e-we-pe-se-so-me-na and the Question of an Early Greek Umlaut). In M Fritz, S Zeilfelder (eds.), Indogermanica. Festschrift fur Günter Neumann zum 80, pp. 201-213. Geburtstag, Graz: Leykam.

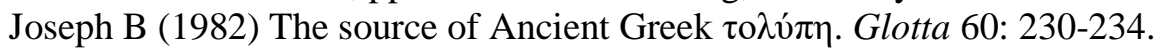

Hooker JT (1988) From Mycenae to Homer. In JH Betts, JT Hoooker, JR Green (eds.), Studies in Honour of T.B.L. Webster, pp. 57-64. Bristol: Bristol Classical Press.

Killen JT (1984) The Textile Industries at Pylos and Knossos. In TG Palaima, CW Shelmerdine (eds.), Pylos Comes Alive: Industry and Administration in a Mycenaean Palace. Papers of a Symposium pp. 49-63. New York: Fordham University.

LIV = Kümmel M, Rix H (eds.) (2001) Lexikon der indogermanischen Verben. Die Wurzeln und ihre Primärstammbildungen. Zweite, erweiterte und verbesserte Auflage bearbeitet von Martin Kümmel und Helmut Rix (Lexicon of IndoEuropean Verbs. The Roots and their Primary Root Formations. Second Expanded and Revised Edition by Martin Kümmel and Helmut Rix). Wiesbaden: Reichert.

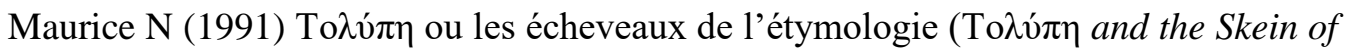
its Etymology). Revue de philologie de litterature et d'histoire anciennes 65: 161167.

McIntosh Snyder J (1981) The Web of Song: Weaving Imagery in Homer and the Lyric Poets. The Classical Journal 76 (3): 193-196.

Melchert HC (1993) Cuneiform Luwian Lexicon. Chapel Hill, NC: University of North Carolina at Chapel Hill. 
Melchert HC (1998) Once more Greek $\tau 0 \lambda v ́ \pi \eta$. Orpheus 8 (Memorial Volume for V. Georgiev): 47-51.

Morpurgo Davies A (1963) Mycenaeae Graecitatis Lexicon. Roma: Edizioni dell'Ateneo.

Morpurgo Davies A (1979) Terminology of power and terminology of work. In E Risch, H Mühlestein (eds.), Colloquium Mycenaeum, pp. 87-108. Genève: Droz.

Murray AT (1919) Homer. The Odyssey with an English Translation, 2 voll. London: Heinemann/Cambridge, MA: Harvard University Press.

Murray AT (1924) Homer. The Iliad with an English Translation, 2 voll. London: Heinemann/Cambridge, MA: Harvard University Press.

Nosch ML (2014a) Voicing the Loom: Women, Weaving and Plotting. In D Nakassis, J Gulizio, SA James (eds.), Ke-ra-me-ja. Studies presented to C.W. Shelmerdine, pp. 91-101. Philadelphia: INSTAP Academic Press.

Nosch ML (2014b) Mycenaean Wool Economies in the Latter Part of the $2^{\text {nd }}$ Millennium Aegean. In C Breniquet, $\mathrm{C}$ Michel (eds.), Wool Economy in the Ancient Near East and the Aegean, pp. 371-400. Oxford: Oxbow.

Palmer LR (1963) The Interpretation of Mycenaean Greek Texts. Oxford: Clarendon Press.

Pantelia MC (1993) Spinning and Weaving: Ideas of Domestic Order in Homer. American Journal of Philology 114 (4): 493-501.

Perpillou JL (1996) Recherches lexicales en Grec Ancien. Étymologie, Analogie, Représentations (Lexical Studies in Ancient Greek. Etymology, Analogy, Representations). Louvain - Paris: Peeters.

Schmitt R (1967) Dichtung und Dichtersprache in indogermanischer Zeit (Poetry and Poetic Language in Indo-European Time). Wiesbaden: Harrassowitz

Shelmerdine CW (2008) The Aegean Bronze Age. Cambridge: Cambridge University Press.

Watkins C (1995) How to Kill a Dragon. Aspects of Indo-European Poetics. New York, Oxford: Oxford University Press.

West M (2007) Indo-European Poetry and Myth. Oxford: Oxford University Press. 